International Journal of Agriculture, Environment and Bioresearch

Vol. 5, No. 05; 2020

ISSN: $2456-8643$

\title{
INCIDENCE, SEVERITY AND YIELD LOSS OF POWDERY MILDEW DISEASE OF RASPBERRY AND EFFICIENCY OF FUNGICIDES AGAINST IT IN UZBEKISTAN
}

\author{
Gayrat Khusanovich Jumanazarov ${ }^{1}$ and Mirakbar Abzalovich Zuparov ${ }^{2}$ \\ ${ }^{1}$ Independent Researcher, Assistant of the Department Agrobiotechnology, \\ Tashkent State Agrarian University, Tashkent, Uzbekistan \\ ${ }^{2}$ Candidate of Biological Sciences, Associate Professor of the Department Agrobiotechnology, \\ Tashkent State Agrarian University, Tashkent, Uzbekistan \\ https://doi.org/10.35410/IJAEB.2020.5562
}

\begin{abstract}
Like other crops, raspberry plant gets infected by many infectious diseases. Among them, powdery mildew disease causes significant damage. This article outlines the results of the study on the pathogens of powdery mildew disease of raspberry, incidence of diseases on the farms, as well as severity of diseases. Besides, the data on yield loss of this disease and testing of the fungicides against powdery mildew disease of raspberry with active ingredients Flusilazole, Difenoconazole + ciflufenamid and Penconazole have been presented. In this case, fungicides against powdery mildew were used during the emergence of the first flower buds of raspberry and in the periods before flowering. The highest biological efficacy was noted in the variants with fungicide Cideli Top 140 DC (125 g/l Difenoconazole $+15 \mathrm{~g} / \mathrm{l}$ ciflufenamid) and its indication was 79,6-90,0\%. At a rate $0,7 \mathrm{l} /$ ha, twice application of Cideli Top $140 \mathrm{DC}$ fungicide during the emergence of the first buds of raspberry and before flowering resulted effectively and its biological efficacy showed 90,0\%. While in the variants with fungicide Omad, $40 \% \mathrm{EC}$, biological efficacy was $71,9-80,5 \%$.
\end{abstract}

Keywords: Raspberry, powdery mildew, diseases, fungi, incidence of diseases, severity of diseases, fungicide, biological efficacy.

\section{INTRODUCTION}

In recent years, in Uzbekistan consistent reforms in the field of protection of medicinal plants of the local flora, rational use of natural resources, improvement of the ecological situation, the establishment of plantations and their processing have been carried out. In this regard, the Resolution of the President of the Republic of Uzbekistan dated April 10, 2020 "On measures for the protection, cultivation, processing and rational use of available resources of wild-growing medicinal plants" is of great relevanance. Out of more than 4,300 plants belonging to the local flora, 750 species are medicinal, of which 112 species are registered for use in scientific medicine, of which 70 species are actively used in the pharmaceutical industry. It can be said that in 2019, products from processed medicinal plants worth US \$ 48 million were exported [1].

The fruits and leaves of raspberry are used as medicine. Sugar in raspberry fruits makes 5,7-12\% (glucose, sucrose, fructose, etc.), and also there are organic acids (citric, malic acid, salicylic 
acid, etc.), dyes, essential oils (the specific aroma of the fruit is more depending on these oils), vitamins $\mathrm{C}, \mathrm{B}$ and others [2].

In modern folk medicine, raspberries - its fruits, a decoction of leaves, are used as a diaphoretic, antifebrile, expectorant remedy, also against the cold and fever. A decoction of the leaves is also used for diarrhea, various bleeding. A decoction of raspberry flowers is recommended for washing against acne, skin inflammations. In Indian folk medicine, raspberries are considered astringent, antiemetic and tonic remedy. It is prescribed for violations of menstruation, uterine bleeding, inflammatory diseases [3].

In modern scientific medicine, raspberries are recommended as a low-calorie product rich in vitamins and microelements. Thanks to phenolic acids, ellagitannins, anthocyanins, raspberries have antioxidant, anti-inflammatory properties $[4,5]$. Raspberry leaf extracts contribute to the rapid recovery of the body after physical activity, that is, they have actoprotective properties [6]. It was also revealed that raspberry extracts have immunomodulatory properties [7]. For patients recovering from infectious diseases, the fruits of the raspberry are much more energetic and appetizing. It was proven that the febrifuge effect of raspberry depends on the salicylic acid it contains [8].

According to the data of FAO, in 2018, 870,2 thousand tons of raspberry were grown worldwide. The Russian Federation is the leader in raspberry growing, with 165580 tons of raspberry cultivated in 2018. In the production of raspberry, the next countries in the world are Mexico (130187 tons), Serbia (127010 tons) and Poland (115613 tons) [9].

Growing medicinal plants, protecting them from pests and using them wisely require the cooperation of specialists in many fields. In this regard, specialists have a number of tasks, including the preservation of the gene pool of medicinal plants, their cultivation, the creation of high-yielding varieties, the creation of gene banks, protection of natural resources from diseases and pests and rational use of products.

A number of research work and studies have been conducted on the diseases of raspberry plant. The most common diseases of raspberry are anthracnose, downy mildew, rust, white blister, gray rot, bacterial canker, canker spots, powdery mildew, verticillium and fusarium wilt, root rot, leaf spot, phyllosticta leaf spot, bacteriosis and viral diseases $[10,11]$.

She points out that these diseases come in two different forms, the diseases that occur in the stem and the leaf, among which the most harmful are the diseases in the form of stems.

While anthracnose disease of raspberry was first diagnosed in the territory of former Soviet Union in the late 1950s and early 1960s of XX century, it is now reported to be present everywhere where the raspberry is grown [11].

\section{MATERIALS AND METHOD}

We studied the species composition of diseases encountered in raspberry plant in our experiments. Experiments on the study of the species composition of diseases of raspberry plant 
were carried out in 2017-2019 in the fields of farms "Kumushkon Bakht", "Kumushkon Gold" and "BB Agro 1" in Tashkent region, as well as to determine the species composition of pathogen of powdery mildew the laboratory experiments were conducted at Agrobiotechnology Department of Tashkent State Agrarian University.

As a result of observations in raspberry fields of farms in Tashkent region, the disease was detected in all plantations.

Solid nutrient media and a moisture chamber were used to isolate pure cultures of pathogenic fungal species from damaged specimens of raspberry plant [12].

Microscopes MICMED-5, Optika B-292, NiB-100 were used to identify pathogenic fungal species isolated from plants.

To determine fungi species, the determiners of N.M.Pidoplychko [13], V.I.Bilay [14] and others were used.

During the experiments conducted in small fields and industrial conditions for trials of fungicides against powdery mildew disease of raspberry, different concentrations of fungicides Omad, 40\% EC (400 g/l Flusilazole), CideliTop140 DC (125 g/l Difenoconazole + 15 g/l ciflufenamid) and Topaz, 10\% EC (100 g/l Penconazole) were tested (Table 1).

Table 1. Description of fungicides used in the experiment

\begin{tabular}{|c|c|c|c|c|}
\hline № & Active ingredient & Trade name & Formulations* & Chemical class \\
\hline $\mathbf{1}$ & Flusilazole & Omad & EC, $400 \mathrm{~g} / \mathrm{l}$ & Triazole \\
\hline $\mathbf{2}$ & $\begin{array}{c}\text { Difenoconazole }+ \\
\text { ciflufenamid }\end{array}$ & Cideli Top & $\begin{array}{c}140 \mathrm{DC} \\
(125 \mathrm{~g} / \mathrm{l}+15 \mathrm{~g} / \mathrm{l})\end{array}$ & $\begin{array}{c}\text { Triazole }+ \\
\text { phenylacetamids }\end{array}$ \\
\hline $\mathbf{3}$ & Penconazole & Topaz & $\mathrm{EC}, 100 \mathrm{~g} / \mathrm{l}$ & Triazole \\
\hline
\end{tabular}

* EC-Emulsifiable Concentrate; DC-Dispersible Concentrate

Decrease of contamination rate of infected raspberry plant by pathogens in the variants treated with fungicides and biological preparations identified in percentage comparing to control variant, and biological efficacy of preparations has been found according to the following formulae:

$$
\mathrm{Ec}=\frac{\left(\mathrm{PH}_{\mathrm{H}}-\mathrm{PT}\right)}{\mathrm{PH}_{\mathrm{H}}} \times 100 ;
$$

Бc $\neg \neg-$ biological efficacy of fungicide, $\%$;

$\mathrm{PH}_{\mathrm{H}} \neg \neg$ severity of diseases in control variant, \%;

$\mathrm{PT}_{\mathrm{T}} \neg-$ severity of diseases in experimental variant, \% [15].

Statistical analysis of study results was performed by the method of B.A.Dospekhov [16].

\section{RESULTS AND DISCUSSION}


Growing shoots and young leaves of raspberry were infected by powdery mildew disease. The reticulate white dust of the pathogenic fungus appeared on the upper and lower surface of the young leaves, in a certain part of the leaf petiole, and rarely on the tips of the growing shoots. In a favorable condition when the humidity was high enough, the dust took on a powdery appearance and became noticeable. Under unfavorable conditions for the growth of the fungus, the dust was not visible, as the hairs covering the leaves of the fungus prevented this. Infected leaves stopped growing, discolored, the petioles became thinner. Dust in plant organs was found to consist of fungal mycelium and conidia.

According to references [17], the pathogenic fungus goes through a period of conidia and cyst formation in its development.

During the formation of the conidia (Oidium sp.), its conidia coalesced to form a chain, which had an elongated shape, covered with a colorless, thin film, measuring 27-36 $\times 15-17 \mu \mathrm{m}$.

Studies have not shown that the fungus that causes this disease produces cleistothecia fruit bodies belonging to cyst forming period.

Analysis of samples of raspberry plant infected with powdery mildew disease was carried out in the laboratory. The plant samples presented for this purpose were planted under sterile conditions in a Petri dish in a moisture chamber and in Petri dishes with Czapek dox agar, beer wort agar, agar potato medium. Petri dishes with infected specimens of raspberry plant were placed in a thermostat at $24-26^{\circ} \mathrm{C}$ to allow the pathogen to grow, and they were observed from the third day. Fungi grown from diseased specimen fragments were inoculated in tubes with agar wort nutrient media.

When pure cultures of isolated fungi were observed under a microscope and measurements were taken in the preparation, it was determined that these fungal cultures belonged to the genus Sphaerotheca macularis Magnus.

As a result of our observations of the study in the farms "Kumushkon Bakht", "Kumushkon Gold" and "BB Agro 1" in Tashkent region, it was noted that the disease was less prevalent in the farm "BB Agro 1". It was observed that the incidence of powdery mildew disease in this farm was $12,5 \%$ and its severity was 5,3\% (Table 2). These indications were $28,2 \%$ and $22,7 \%$ in "Kumushkon Bakht" farm, respectively and 31,4\% and 25,2\% in "Kumushkon Gold" farm. When analyzing the effect of powdery mildew disease on the yield of plant, it was noted that due to this disease, "BB Agro 1" farm lost relatively less yield, which was 10,9\%. Yield loss under disease effect was 20,0\% in "Kumushkon Bakht" farm, and 22,7\% in "Kumushkon Gold" farm.

Table 2.The incidence, severity and yield loss of powdery mildew disease in raspberry plant

\begin{tabular}{|c|c|c|c|c|c|c|c|c|}
\hline \multirow{2}{*}{ № } & Farms & $\begin{array}{c}\text { Incidence } \\
\text { of } \\
\text { diseases }\end{array}$ & $\begin{array}{c}\text { Severity } \\
\text { of } \\
\text { diseases }\end{array}$ & $\begin{array}{c}\text { Diseas } \\
\text { Index, }\end{array}$ & \multicolumn{2}{|c|}{$\begin{array}{c}\text { Mean yield per plant, } \\
\text { kg }\end{array}$} & $\begin{array}{c}\text { Yield loss relative to } \\
\text { healthy plant }\end{array}$ \\
\cline { 5 - 9 } & & $\%$ & $\%$ & $\%$ & $\begin{array}{c}\text { Healthy } \\
\text { plant }\end{array}$ & $\begin{array}{c}\text { Infected } \\
\text { plant }\end{array}$ & kg & $\%$ \\
\hline & $\begin{array}{c}\text { "Kumushkon } \\
\text { Bakht" }\end{array}$ & 28,2 & 22,7 & 6,4 & 2,50 & 2,00 & 0,50 & 20,0 \\
\hline
\end{tabular}


International Journal of Agriculture, Environment and Bioresearch

Vol. 5, No. 05; 2020

ISSN: $2456-8643$

\begin{tabular}{|c|c|c|c|c|c|c|c|c|}
\hline $\mathbf{2}$ & $\begin{array}{c}\text { "Kumushkon } \\
\text { Gold" }\end{array}$ & 31,4 & 25,2 & 7,9 & 2,20 & 1,70 & 0,50 & 22,7 \\
\hline $\mathbf{3}$ & "BB Agro-1" & 12,5 & 5,3 & 5,9 & 2,30 & 2,10 & 0,25 & 10,9 \\
\hline & $\mathbf{L S D}_{\mathbf{0 5}}$ & $\mathbf{1 . 1 7}$ & $\mathbf{2 . 5 2}$ & & & & & \\
\hline
\end{tabular}

The effect of some fungicides against powdery mildew, approved for use in the Republic of Uzbekistan, was studied.

When using fungicides against powdery mildew, it is important to choose the right method and timing so that the residues of these chemicals do not remain in the plant organs. Great attention was paid to these aspects during the experiments.

The experiments conducted in small fields and industrial conditions for trials of fungicides against powdery mildew disease of raspberry were carried out in "Kumushkon Bakht" farm in Parkent district of Tashkent region. The trials were conducted against powdery mildew disease of raspberry according to guideline. Fungicides Omad 40\% e.c. (400 g/l) and Cideli TOP 140 d.c. $(125 \mathrm{~g} / \mathrm{l}+15 \mathrm{~g} / \mathrm{l})$ against powdery mildew were tested at three rates. As a standard fungicide Topaz $10 \%$ e.c. $(100 \mathrm{~g} / \mathrm{l})$ was used and as a control the raspberry plants without fungicide treatment were used in the experiment.

Table 3.The effect of fungicides on powdery mildew disease of raspberry in small field experiments

(2017, "Kumushkon Bakht" farm)

\begin{tabular}{|c|c|c|c|c|c|c|c|c|c|c|c|c|}
\hline \multirow{2}{*}{ № } & \multirow{2}{*}{ Variants } & \multirow{2}{*}{$\begin{array}{c}\text { Fungicides } \\
\text { consumption }\end{array}$} & \multicolumn{10}{|c|}{ Fungicide treatment time } \\
\hline & & & \multicolumn{3}{|c|}{$\begin{array}{l}\text { During emergence of the first } \\
\text { flower buds }\end{array}$} & \multicolumn{4}{|c|}{ Pre-flowering period } & \multicolumn{3}{|c|}{$\begin{array}{l}\text { During emergence of the first } \\
\text { flower buds and pre-flowering } \\
\text { period }\end{array}$} \\
\hline 1 & $\begin{array}{l}\text { Omad } 40 \% \text { e.c. } \\
(400 \mathrm{~g} / \mathrm{l})\end{array}$ & 0,05 I/ha & 12,8 & 7,5 & 67,5 & 13,6 & & 7,9 & 65,8 & 11,1 & 6,5 & 71,9 \\
\hline 2 & Cideli TOP 140 d.k. & $0,5 \mathrm{l} / \mathrm{ha}$ & 8,9 & 5,2 & 77,5 & 10,8 & & 6,3 & 72,7 & 8,1 & 4,7 & 79,6 \\
\hline
\end{tabular}


International Journal of Agriculture, Environment and Bioresearch

Vol. 5, No. 05; 2020

ISSN: $2456-8643$

\begin{tabular}{|c|c|c|c|c|c|c|c|c|c|c|c|}
\hline & $(125 \mathrm{~g} / \mathrm{l}+15 \mathrm{~g} / \mathrm{l})$ & 0,6 I/ha & 5,3 & 3,1 & 86,6 & 7,2 & 4,2 & 81,8 & 4,5 & 2,6 & 88,7 \\
\hline & & 0,7 I/ha & 4,6 & 2,7 & 88,3 & 6,0 & 3,5 & 84,8 & 4,1 & 2,3 & 90,0 \\
\hline & $L S D_{05}$ & & & & & & & & 2.30 & 1.92 & \\
\hline
\end{tabular}

Table 4. The effect of fungicides on powdery mildew disease of raspberry in small field experiments

(2018-2019, “Kumushkon Bakht" farm)

\begin{tabular}{|c|c|c|c|c|c|c|c|c|c|c|c|c|c|c|}
\hline \multirow{3}{*}{$\mathbf{N}$} & \multirow{3}{*}{ Variants } & \multirow{3}{*}{$\begin{array}{l}\text { Fungicides } \\
\text { consump- } \\
\text { tion }\end{array}$} & \multicolumn{9}{|c|}{ Fungicide treatment time } & \multirow{3}{*}{$\begin{array}{l}\text { The } \\
\text { yield per } \\
\text { plant, } \\
\text { kg }\end{array}$} & \multirow{2}{*}{\multicolumn{2}{|c|}{$\begin{array}{l}\text { Protected } \\
\text { (preserved) } \\
\text { yield } \\
\text { relative to } \\
\text { the control }\end{array}$}} \\
\hline & & & \multicolumn{3}{|c|}{$\begin{array}{l}\text { During emergence of the } \\
\text { first flower buds }\end{array}$} & \multicolumn{3}{|c|}{ Pre-flowering period } & \multicolumn{3}{|c|}{$\begin{array}{l}\text { During emergence of the } \\
\text { first flower buds and pre- } \\
\text { flowering period }\end{array}$} & & & \\
\hline & & & 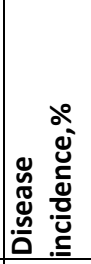 & 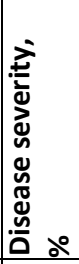 & $\begin{array}{l}\text { Biological } \\
\text { efficacy of } \\
\text { fungicides, } \\
\%\end{array}$ & 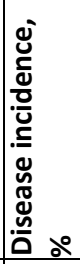 & 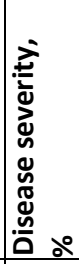 & $\begin{array}{l}\text { Biological } \\
\text { efficacy of } \\
\text { fungicides } \\
\% \\
\%\end{array}$ & 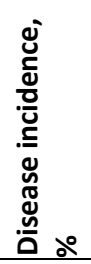 & 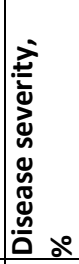 & $\begin{array}{l}\text { Biological } \\
\text { efficacy of } \\
\text { fungicides } \\
\%\end{array}$ & & kg & $\%$ \\
\hline 1 & $\begin{array}{l}\text { Cideli TOP } 140 \\
\text { d.k. }(125 \mathrm{~g} / \mathrm{l}+15 \\
\mathrm{g} / \mathrm{l})\end{array}$ & $0,7 \mathrm{I} / \mathrm{ha}$ & 6,4 & 3,8 & 83,0 & 7,1 & 4,1 & 81,7 & 6,1 & 2,5 & 88,8 & 2,5 & 0,5 & 20,0 \\
\hline 2 & $\begin{array}{l}\text { Topaz } 10 \% \text { e.c. } \\
\text { (100 g/I) } \\
\text { (Standard) }\end{array}$ & $\begin{array}{l}0,25 \\
\text { l/ha }\end{array}$ & $\begin{array}{l}11 \\
8\end{array}$ & 6,9 & 69,2 & $\begin{array}{l}12, \\
4\end{array}$ & 7,2 & 67,9 & 10,9 & 3,7 & 83,5 & 2,3 & 0,3 & 13,0 \\
\hline 3 & $\begin{array}{l}\text { Control (without } \\
\text { fungicide) }\end{array}$ & - & $\begin{array}{l}38, \\
1\end{array}$ & $\begin{array}{l}22, \\
4\end{array}$ & - & $\begin{array}{l}38, \\
1\end{array}$ & $\begin{array}{l}22, \\
4\end{array}$ & - & 38,1 & $\begin{array}{l}22, \\
4\end{array}$ & - & 2,0 & - & - \\
\hline & $L S D_{05}$ & & & & & & & & 2.34 & $\begin{array}{l}1.7 \\
6\end{array}$ & & & & \\
\hline
\end{tabular}

The fungicides against powdery mildew were applied to plants when the first flower buds appeared and pre-flowering period. The fungicides used against the powdery mildew disease of raspberry and all their application rates showed good results. The best results were observed in the variants with fungicide Cideli TOP 140 d.c. and its biological efficacy was 79,6-90,0\% 
(Table 3). Treatment with this fungicide at a rate of 0,71 /ha when the first flower buds of the plant appeared and twice before flowering gave good results, its biological efficiency showed $90,0 \%$. In Omad $40 \%$ e.c. fungicide applied variants the biological efficiency was $71,9-80,5 \%$. In the standard variant, this indication was $84,8 \%$.

A rate 0,71 /ha of Cideli TOP 140 fungicide, which showed effective results in small field experiments, was selected for production experiments. As a result of the research conducted, the best indication was noted in the variant where twice treatment to raspberry plant with fungicide Cideli TOP 140 d.c. at rate of $0,7 \mathrm{l} /$ ha when the first flower buds appear and prebloom period, and its biological efficiency made $88,8 \%$, and 20,0\% yield was saved (Table 4). In standard variant with the application of fungicide Topaz $10 \%$ e.c. the biological efficacy was $83,5 \%$ and the saved yield made $13,0 \%$.

\section{CONCLUSIONS}

Based on the data obtained during the observations of the study it can be concluded that powdery mildew disease of raspberry was recorded in all raspberry farms and its causative agent was Sphaerotheca macularis Magnus.fungus species.

Among raspberry producing farms the highest indication on the incidence and severity of disease was observed in "Kumushkon Gold" farm (incidence of diseases - 31,4\%; severity of diseases $25,2 \%$ ), while the lowest indication was in "BB Agro 1" farm (incidence of diseases - 12,5\%; severity of diseases $-5,3 \%$ ), .

Against powdery mildew disease of raspberry, the fungicide Cideli TOP 140 DC with active ingredient- $125 \mathrm{~g} / \mathrm{l}$, Difenoconazole $+15 \mathrm{~g} / \mathrm{l}$, ciflufenamid had the highest biological efficacy, when it was applied twice at rates 0,$5 ; 0,6 ; 0,71 /$ ga (emergence of the first flower buds and prebloom) its biological efficacy showed $79,6 \% ; 88,7 \% 90,0 \%$ respectively. Therefore, the fungicide Cideli Top 140 DC is recommended to be applied twice to the plant: during the emergence of the first flower buds and before flowering at the rates $0,61 /$ ha or $0,71 /$ ha.

\section{REFERENCES}

[1] Medicinal plants - are natural resources of the country. https://kun.uz/news/2020/04/16/dorivor-osimliklar-mamlakatning-tabiiy-boyligidir, 16.04.2020. (In Uzbek)

[2] Lyogkaya L.V., Lypskaya S.L. Biochemical composition of fruits of remontant type raspberry varieties // Fruit growing: sci.conf. RUP "Institute of fruit growing". Samokhvalovichy, (2008), Vol. 20. pp. 195-201. (In Russian)

[3] Karamatov I. J. Simple medicines. Publ.house: Bukhara "Durdona", (2012), p. 888. (In Russ.)

[4] Akopov I.E. The most important domestic medicinal plants and their use Tashkent, Medicine, (1986), p.568. (In Russ.) 
[5] Beekwilder J., Jonker H., Meesters P., Hall R.D., van der Meer I.M., Ric de Vos C.H. Antioxidants in raspberry: on-line analysis links antioxidant activity to a diversity of individual metabolites. Journal of Agricultural and Food Chemistry, (2005), May 4, 53(9), pp. 3313-3320. (In English)

[6] Chekhany N.R., Pavlova L.A., Kozyn S.V., Teselkin Yu.O. Evaluation of the chemical composition and specific pharmacological action of a new actoprotective agent. Butlerovsky refernces, (2014), Vol. 38, No 4, pp. 58-62. (In Russ.)

[7] Mace T.A., King S.A., Ameen Z., Elnaggar O., Young G., Ried K.M., Schwartz S.J., Clinton S.K., Knobloch T.J., Weghorst C.M., Lesinski G.B. Bioactive compounds or metabolites from black raspberries modulate $\mathrm{T}$ lymphocyte proliferation, myeloid cell differentiation and Jak/STAT signaling. Cancer. Immunol. Immunother. (2014), Sep., 63(9), pp. 889-900. doi: https://doi.org/10.1007/s00262-014-1564-5 (In English)

[8] Gulyaev D.K., Belonogova V.D., Rudakova I.P. Composition and biological activity of polysaccharides of shoots and leaves of raspberry (Rubus idaeus L.). Traditional medicine, (2017), No 4. pp. 39-42. (In Russ.)

[9] FAOstat, (2017). http://www.fao.org/faostat/en/\#data/QC

[10] Natalina O.B. Diseases of berry culture. (Reports - generalization of published scientific works submitted for obtaining academic degree doct. biol. sciences). -Leningrad, (1965), p.78. (In Russ.)

[11] Ryabkova N.A., Agafonova Z.A. Raspberry diseases and pests. Leningrad: Kolos. (1977). p.56. (In Russ.)

[12] Khohryakov M.K. Guidelines for the experimental study of phytopathogenic fungi. Leningrad, (1969), p.68. (in Russ.)

[13] Pidoplychko N.M. Fungi - parasites of cultured plants. II vol.- Kiev: Naukova dumka, (1977), p.300. (in Russ.)

[14] Bilay V.I. Fusarium. -Kiev: Naukova dumka. (1977). p. 443. (in Russ.)

[15] Dementyeva M.I. Phytopathology. Moscow: Agropromizdat, (1985). p. 397. (in Russ.)

[16] Dospekhov B.A. Methodics for field experiments. Moscow: Agropromizdat. (1985), p. 351. (in Russ.)

[17] Natalina O.B. Berry diseases. Moscow: Selkhozgiz. (1963). p.272. (in Russ.) 